\title{
Daylight Intensity of Reading Room with Shading Device's Opening (Case Study: The Library of Universitas Budi Luhur, South Jakarta)
}

\author{
Sri Kurniasih \\ Dept. of Architecture \\ Universitas Budi Luhur \\ Jakarta, Indonesia \\ sri.kurniasih@budiluhur.ac.id
}

\author{
Inggit Musdinar S.S.Y.M \\ Dept. of Architecture \\ Universitas Budi Luhur \\ Jakarta, Indonesia \\ inggit.musdinar@budiluhur.ac.id
}

\author{
Bagus Nurhasan Rachmanto \\ Dept. of Architecture \\ Universitas Budi Luhur \\ Jakarta, Indonesia \\ bagusnurhasan3@gmail.com
}

\begin{abstract}
Daylight entering through the window can be obtained from several sources, namely direct sunlight, clear sky, clouds or reflections of the lower surface and surrounding buildings. Light from each source differs not only in the amount and heat it carries, but also in other qualities, such as color, distribution, and savings. To get natural lighting in the space required large windows or glass walls at least $1 / 6$ of the floor area. Light is the most important part of human life, to get the right lighting in a space, it is necessary to design the right natural lighting according to their needs so that visual comfort can be achieved. Visual comfort is the recommended lighting level that does not exceed the stated threshold and brightness level, and no glare space occurs. Not only to illuminate a room, but the level of lighting also affects the condition of the room created. But visual comfort will be disrupted if glare problems occur. Visual disturbances in the form of "glare" affect visual performance which adversely affects the ability to see. Based on previous research, it was found that the average value of the natural lighting intensity in the reading room of the 3rd floor of the library of Budi Luhur University was 663 lux, this shows that the average value of the natural lighting intensity that occurred exceeded SNI standards and caused glare problems that could interfere with comfort library users, so there needs to be a natural lighting system strategy that can be applied to achieve visual comfort in the library reading room on the 3rd floor. This research was conducted with the main objective is to get a shading device design solution that can reduce glare problems to achieve visual comfort. The research method used in this study is a quantitative research method with an experimental approach. The variables in this study are experimental variables (visual comfort, opening orientation, shading device design) and nonexperimental variables (direct light source, sky conditions, and direct glare). The stages of this research are in the form of; i) identification and data collection in the form of library studies related to natural lighting, visual comfort and shading devices, ii) identification and data collection in the form of library studies related to shading devices, iii) observation of case studies in the form of taking pictures in the form of photographs and work drawings, iv) conducting simulation of several alternative shading devices designs that will be applied to the window openings of the 3rd floor library reading room of Budi Luhur University, v) analysis and synthesis, vi) making research results and drawing conclusions. The results of this study in the form of the most optimal design of shading devices that can reduce lighting intensity is an alternative horizontal overhang 4 design with an overhang width of $200 \mathrm{~cm}$. Whereas the most optimal design of vertical overhang shading devices that can reduce
\end{abstract}

lighting intensity is alternative vertical overhang design 1 with overhang width of $50 \mathrm{~cm}$ and vertical fin distance every $50 \mathrm{~cm}$. devices

Keywords: daylight intensity, visual comfort, glare, shading

\section{INTRODUCTION}

The existence of a library in the world of education is highly prioritized, moreover at a university to support learning and teaching activities, it should be the center of the library's attention. One of them is the library at Budi Luhur University, located in South Jakarta. Budi Luhur University Library operates from Monday to Saturday, with operating hours Monday through Friday open from 08:00 am until 09:00 pm and on Saturdays from 08:00 am until 03:00 pm. Based on operating hours, it should be able to exploit the potential of natural lighting from morning to evening, while at night it depends on artificial lighting.

Natural lighting is lighting that comes from sunlight that appears from morning to afternoon to evening, with the lighting source coming from direct sunlight and the distribution of sunlight or skylight, called diffuse. Natural lighting is intended to get lighting in the room from natural light. The design of natural lighting systems needs to know the availability of natural light received at the local location [1]. The general goal of natural lighting is to produce efficient quality light while minimizing direct glare, reflecting layers, and excess light ratio. Natural light entering through the window can come from several sources, namely direct sunlight, clear sky, clouds or reflections of the lower surface and surrounding buildings. The light from each of these sources varies not only in the amount and heat it carries, but also in other qualities, such as color, dispersion, and savings. To get natural lighting in space required large windows or glass walls of at least $1 / 6$ of the floor area [2].

Visual comfort is the convenience of accessing all visual information and is closely related to the sense of sight [3]. Visual comfort is the recommended lighting level that does not exceed the stated threshold and brightness level, and no glare space occurs. Not only to illuminate a room, but the level of lighting also affects the condition of the room (comfort and pleasure) created [4]. Visual comfort is closely related to the distribution of room light, generally, lighting design uses standards recommended by SNI that explain 


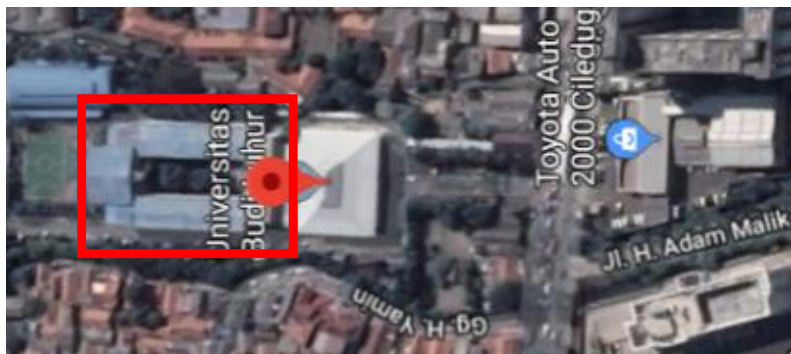

Fig. 1. Map of Budi Luhur University

Source: https://www.google.co.id/maps/place/Universitas+Budi+Luhur reflection. Direct glare is caused by a bright light source that is distracting, uncomfortable or missing in visual performance. Whereas glare due to reflections from light sources on shiny tabletops or polished floors can cause the same problems as direct glare [5].

Based on previous studies, it was found that the average value of natural lighting intensity in the reading room of the 3rd floor of the library of Budi Luhur University was 663 lux, this shows that the average value of natural lighting intensity that occurred exceeded SNI standards and caused glare problems that could interfere with comfort library users, so there needs to be a natural lighting system strategy that can be applied to achieve visual comfort in the library reading room on the 3rd floor [5]. Architectural solutions to get visual comfort and reduce glare in the library reading room both on the 3rd floor can be in the form of shading devices with horizontal overhang and vertical overhang types. However, the design of shading devices needs to be analyzed and studied in more detail in their application to openings or windows in the reading room of the 3rd-floor library of Budi Luhur University. Thus, further research is needed to apply the shading devices design recommendations that will be applied to window openings and prove the level of visual comfort that occurs in the library reading room on the $3 \mathrm{rd}$ floor of Budi Luhur University.

\section{LIBRARY OF BUDI LUHUR UNIVERSITY}

Budi Luhur University Library is a unit that serves to provide information services to the academic community in carrying out the duties of the Higher Education Tri Dharma which includes education, research and community service. Budi Luhur University Library continues to develop itself following the development of science and technology, especially the development of information and communication technology, which is realized by implementing information technology in carrying out activities and providing facilities and infrastructure that supports library users. Data of the noble university library building as follows:

Building name : Unit 3 of the building, 2sc floor, and 3 rd floor

Address : J1. Ciledug Raya Petukangan Utara Jakarta Selatan

Building area : $975 \mathrm{~m}^{2}$

Number of floors : 2 floors
Budi Luhur University Library is located in the unit building 3 floors 2 and 3 floors. The object of research is the 3rd-floor library containing a thesis/thesis room, library headroom, and reading room. Library map can be seen in Figure 2.

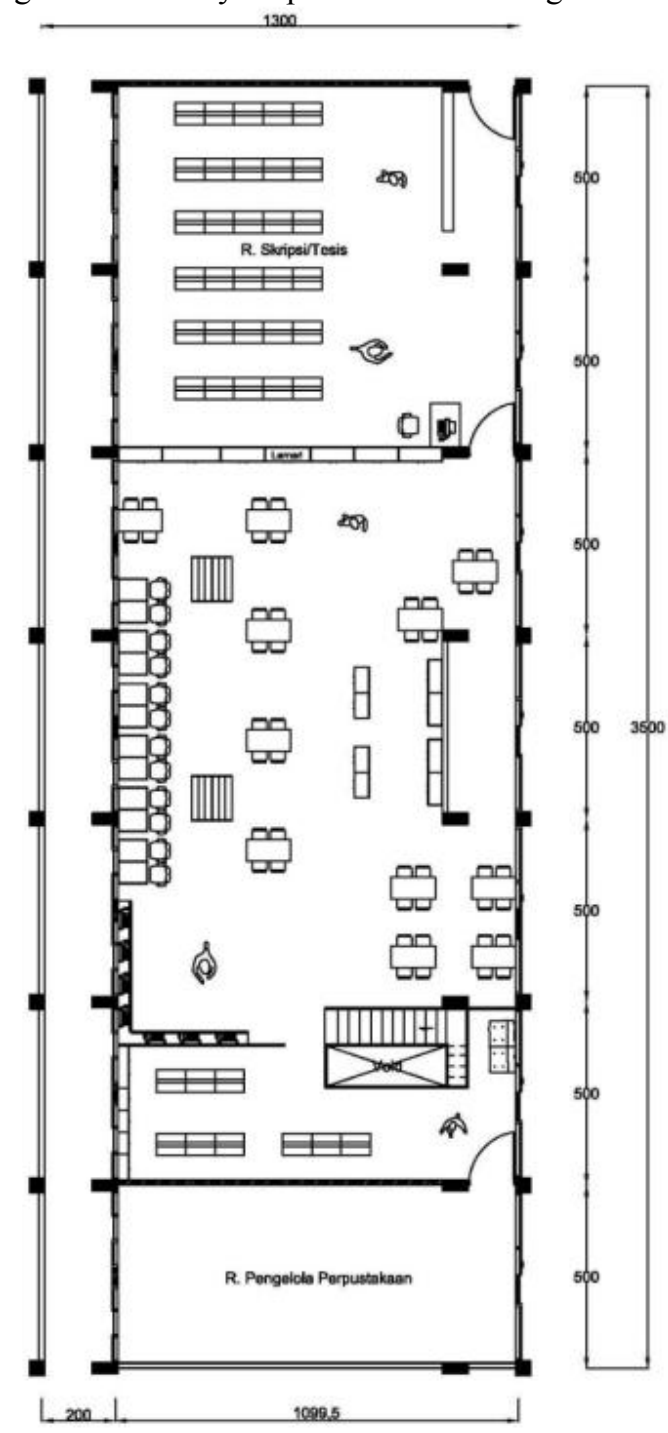

Fig. 2. Floor Plan of the 3rd floor of the Budi Luhur University

The appearance of the Budi Luhur University library building is integrated with the unit 3 building which functions as a classroom. The protrusion of the building's structure columns can be a shading device for wide windows in the reading room that line up throughout the lifetime of the 
library building. The appearance of the library building can be seen in Figure 3.

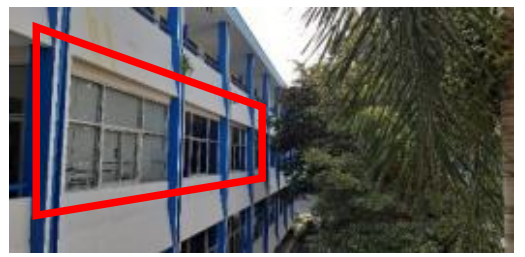

(a) Right side view (East)

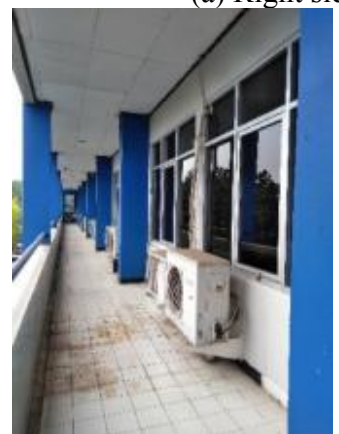

(a) Left side view (West)

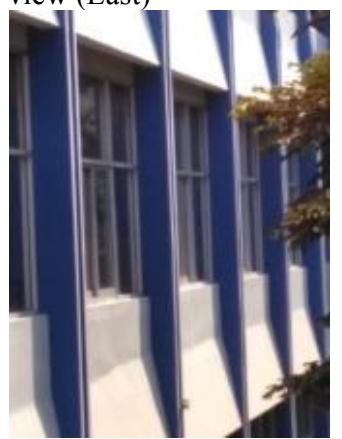

(b) Column protruding out as shading device
Fig. 3. The Facade of the Library Building of Budi Luhur University.

Budi Luhur University Library on the 3rd floor is dominated by reading rooms. The condition of the library's reading room at Budi Luhur University in general experiences glare along the side of the building facing East and West. Although the opening of the window in the reading room is quite wide, the lighting in the reading room is still assisted by artificial lighting, which is using lamps.

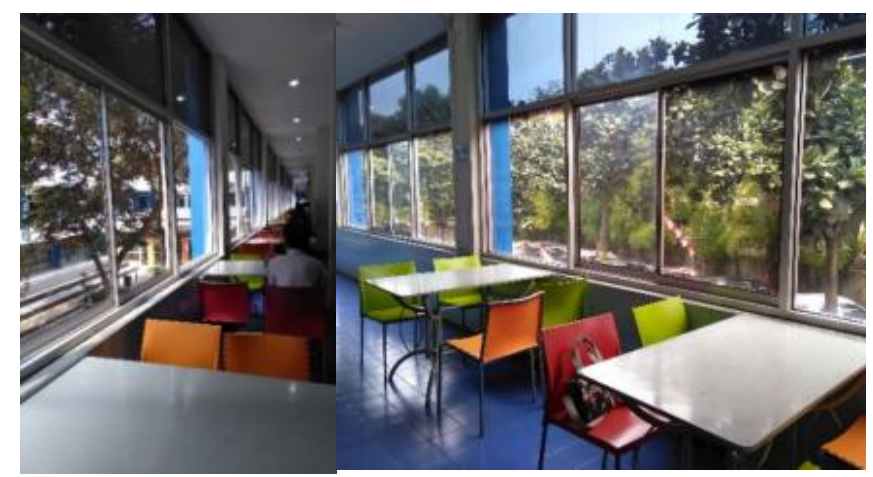

Fig. 4. Lighting conditions on the 3rd-floor reading room

Measurement of natural lighting intensity in the library's reading room at Budi Luhur University has been carried out at each reading table on each floor so that lighting conditions can be represented.

Based on SNI 03-6197-2000 concerning Energy Conservation in Lighting Systems, the average lighting level in a library reading room is $300 \mathrm{~lx}$ [6]. Conditions for measuring lighting levels in the library reading room at BudiLuhur University are:

1. Library reading room on the 3 rd floor with window openings facing East and West.

2. Measurements were made at each reading room table.
3. Measurement Measurements are made at 09:00 a.m, morning at 11:00 a.m. and afternoon at 03.00 a.m. when the sky is clear, in March - April - May - June 2018.

4. Measurements were made of the level of lighting in the reading room with conditions without artificial lighting with a measuring point height of $80 \mathrm{~cm}$.

The results of measurements of lighting levels in the reading room of the 3rd floor of the library of Budi Luhur University can be seen in table 1:

TABLE 1. THE INTENSITY OF NATURAL LIGHTING AVERAGE LIBRARY READING ROOM

\begin{tabular}{|c|c|c|c|c|}
\hline \multirow{2}{*}{ Location } & \multicolumn{2}{|c|}{ The intensity of daylighting (lx) } & \multirow{2}{*}{$\begin{array}{c}\text { Average } \\
\text { daylighting } \\
\text { intensity (Lx) }\end{array}$} \\
\cline { 2 - 4 } & $\begin{array}{c}\text { Time: } \\
\text { 9:00 am }\end{array}$ & $\begin{array}{c}\text { Time: } \\
\mathbf{1 1 : 0 0} \text { am }\end{array}$ & $\begin{array}{c}\text { Time: } \\
\mathbf{3 : 0 0} \mathbf{~ p m}\end{array}$ & \\
\hline $\begin{array}{c}\text { Library } \\
\text { reading } \\
\text { room on } \\
\text { the 3rd } \\
\text { floor }\end{array}$ & 294 & 462 & 1232 & $\mathbf{6 6 3}$ \\
\hline
\end{tabular}

Based on the results of measurements of the intensity of natural lighting in the library reading room on the 3rd floor, the value of natural lighting intensity was $663 \mathrm{~lx}$. The value of the natural lighting intensity exceeds the SNI 03-61972000 standard on Energy Conservation in the Lighting System where the value of lighting intensity for the reading room with the function of the building as a library is $300 \mathrm{~lx}$ [6]. As a result of excessive lighting intensity, heat radiation and glare can occur in the reading room and can disturb the comfort of the user of the room.

\section{RESEARCH METHOD}

The research method used in this study is a quantitative research method with an experimental approach. The quantitative research method is a process of finding the knowledge that uses data in the form of numbers as a tool to analyze information about what you want to know. Experimental research is research conducted to find out the consequences arising from a treatment given intentionally by researchers [7]. Experimental research is research conducted to find out the consequences arising from a treatment given intentionally by researchers [8]. Based on the definitions of some of the experts, it can be understood that experimental research is research conducted to determine the effect of giving a treatment or a treatment of research subjects.

In experimental research, several variables are known. Variables are anything related to conditions, conditions, factors, treatments, or actions that are expected to affect the results of an experiment. Variables that are directly related and applied to find out a particular situation and are expected to have an impact/result from experiments are often called experimental variables (treatment variables), and variables that are not intentionally done but can affect the results of experiments are called non-experimental variables. Experimental variables are conditions that want to be 
investigated for how they affect a symptom. Nonexperimental variables can be partially controlled, both for the experimental group and the control group. This is called a controlled variable. However, some of the nonexperimental variables are outside the power of the experiment to be controlled or controlled. This type of variable is called an extraneous variable or extraneous variable.

The variables used in this study are shown in Table 2.

TABLE 2. VARIABLES IN RESEARCH

\begin{tabular}{|c|c|l|}
\hline $\begin{array}{c}\text { Variable } \\
\text { Type }\end{array}$ & Variable & \multicolumn{1}{c|}{ Sub Variable } \\
\hline $\begin{array}{c}\text { Experimental } \\
\text { Variable }\end{array}$ & Visual Comfort & $\begin{array}{l}\text { Tingkat pencahayaan } \\
\text { alami (intensitas cahaya) }\end{array}$ \\
\hline \multirow{2}{*}{$\begin{array}{c}\text { Opening } \\
\text { orientation }\end{array}$} & Timur - Barat \\
\hline \multirow{2}{*}{$\begin{array}{c}\text { Non- } \\
\text { experimental } \\
\text { variable }\end{array}$} & $\begin{array}{c}\text { Design of } \\
\text { Shading Devices }\end{array}$ & Horizontal Overhang \\
\cline { 2 - 3 } & Control Variable & - \\
\hline & Variables & Natural light source \\
\cline { 2 - 3 } & Sky conditions \\
\cline { 2 - 3 } & & Direct glare \\
\hline
\end{tabular}

The research method used is:

a) Quantitative Method which is to measure the intensity of natural lighting on the window openings that have been applied shading devices in the library reading room on the 3rd floor of Budi Luhur University.

b) Experimental Approach, namely the manufacture and installation of shading devices on window openings to determine the effects of an intentional treatment given by researchers, in this case knowing the consequences of using shading devices on window openings.

\section{SHADING DEVICES}

a. Dimension Calculation for Alternative Design of Shading Devices

Before making the design of shading devices, the thing to do is to determine the dimensions of the shading devices to be designed. This dimension consists of horizontal overhang and vertical overhang dimensions. Based on the library's existing window dimensions, the calculation of the dimensions of the shading devices design is obtained as follows:

\begin{tabular}{|c|c|c|c|}
\hline $\begin{array}{c}\text { No } \\
\text {. }\end{array}$ & $\begin{array}{c}\text { Types of Shading } \\
\text { Devices }\end{array}$ & $\begin{array}{c}\text { Alternative } \\
\text { Design }\end{array}$ & Calculation \\
\hline 1 & $\begin{array}{l}\text { Horizontal } \\
\text { Overhang }\end{array}$ & $\begin{array}{l}\text { Alternative } \\
\text { Horizontal } \\
\text { Overhangs } 1\end{array}$ & $\begin{array}{l}\text { Window } \\
\text { opening height } \\
(\mathrm{H})=200 \mathrm{~cm} \\
\text { Width (L) of } \\
\text { horizontal } \\
\text { overhang: } \\
L=\frac{H}{2} \\
L=\frac{200 \mathrm{~cm}}{2} \\
L=100 \mathrm{~cm}\end{array}$ \\
\hline
\end{tabular}

\begin{tabular}{cccc}
\hline No & $\begin{array}{c}\text { Types of Shading } \\
\text { Devices }\end{array}$ & $\begin{array}{c}\text { Alternative } \\
\text { Design }\end{array}$ & Calculation \\
\hline & The width of the horizontal & \\
\hline
\end{tabular}

The width of the horizontal overhang used is $100 \mathrm{~cm}$.
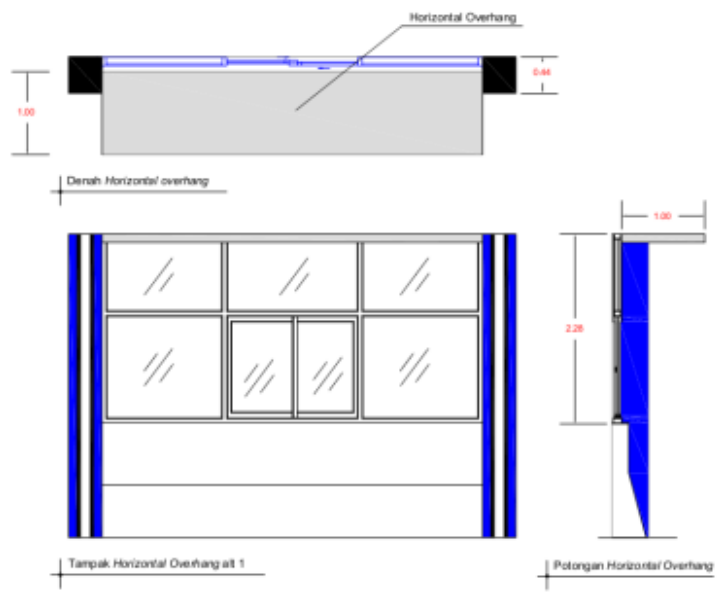

2

$$
\begin{aligned}
& \text { Alternative Window } \\
& \text { Horizontal opening height } \\
& \text { Overhangs } 2 \quad(\mathrm{H})=200 \mathrm{~cm} \\
& \text { Width (L) of } \\
& \text { horizontal } \\
& \text { overhang: } \\
& L=\frac{3 H}{4} \\
& L=\frac{3.200 \mathrm{~cm}}{4} \\
& L=150 \mathrm{~cm}
\end{aligned}
$$

The width of the horizontal overhang used is 150 $\mathrm{cm}$.
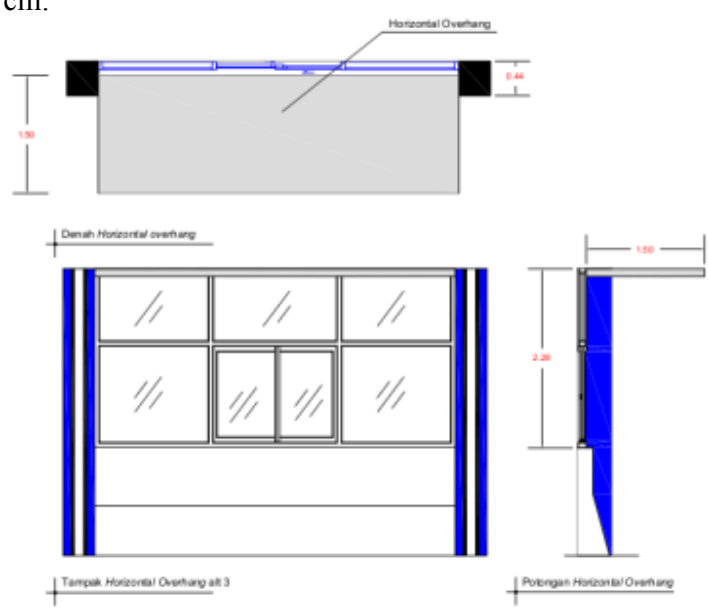

$$
\begin{array}{ll}
\begin{array}{l}
\text { Alternative } \\
\text { Horizontal } \\
\text { Overhangs } 3
\end{array} & \begin{array}{l}
\text { Window } \\
\text { opening height } \\
\text { (H) }=200 \mathrm{~cm} \\
\text { Width (L) of } \\
\text { horizontal } \\
\text { overhang: } \\
L
\end{array} \\
& =\frac{H}{3} \\
& L=\frac{200 \mathrm{~cm}}{3} \\
L & =66,7 \mathrm{~cm} \\
L & =67 \mathrm{~cm}
\end{array}
$$




\begin{tabular}{cccc}
\hline No & $\begin{array}{c}\text { Types of Shading } \\
\text { Devices }\end{array}$ & $\begin{array}{c}\text { Alternative } \\
\text { Design }\end{array}$ & Calculation \\
\hline
\end{tabular}

The width of the horizontal overhang used is $67 \mathrm{~cm}$.
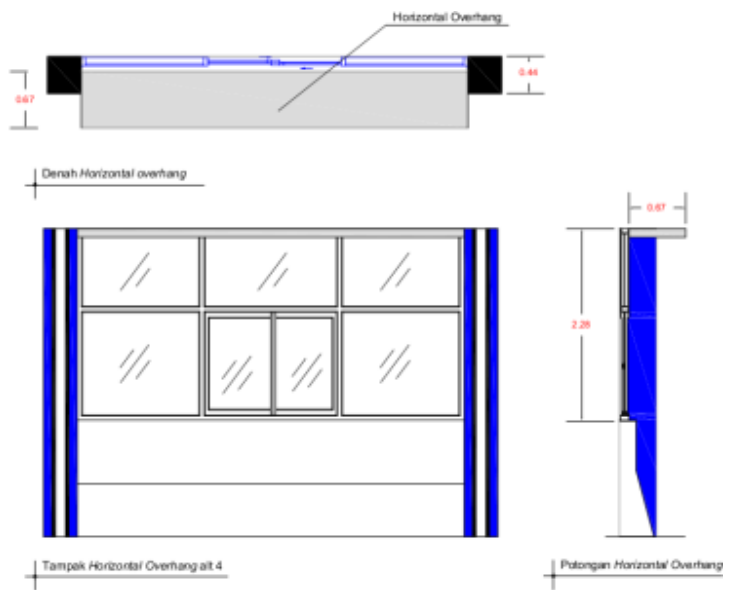

4

$$
\begin{array}{ll}
\text { Alternative } & \text { Window } \\
\text { Horizontal } & \text { opening height } \\
\text { Overhangs } 4 & (\mathrm{H})=200 \mathrm{~cm} \\
& \text { Width (L) of } \\
& \text { horizontal } \\
& \text { overhang: } \\
& L=H \\
& L=200 \mathrm{~cm} \\
& L=200 \mathrm{~cm}
\end{array}
$$

The width of the horizontal overhang used is 200 $\mathrm{cm}$.
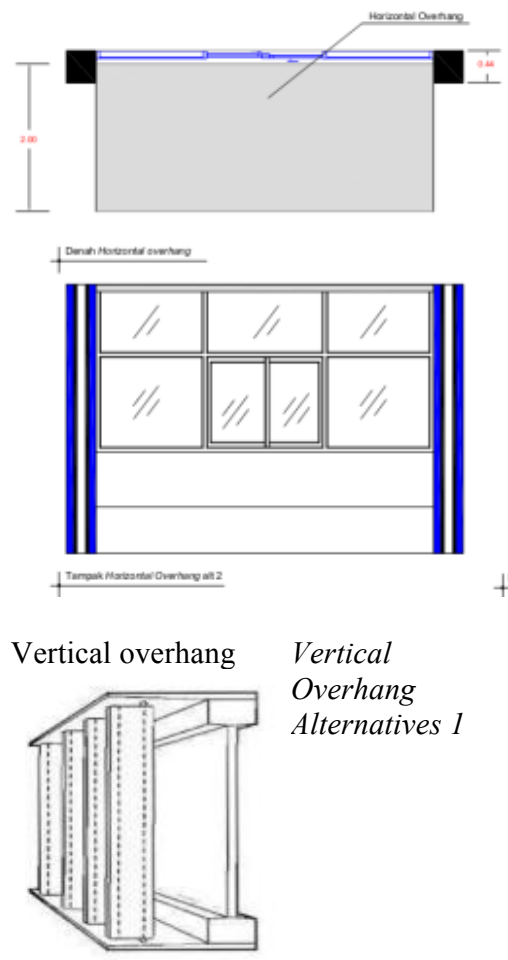

Vertical Overhang Alternatives 1

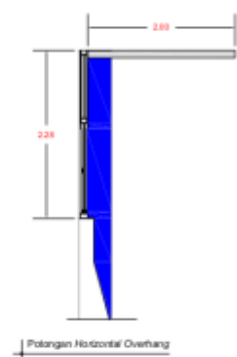

Opening widht $(\mathrm{d})$ $=100 \mathrm{~cm}$

Width (L) of vertical fin:

opening height

(L) $=50 \mathrm{~cm}$

Width (L) of

horizontal

overhang:

$d$

$\frac{d}{L}=1$

$\frac{d}{50 \mathrm{~cm}}=1$

$d=50 \mathrm{~cm}$
Calculation

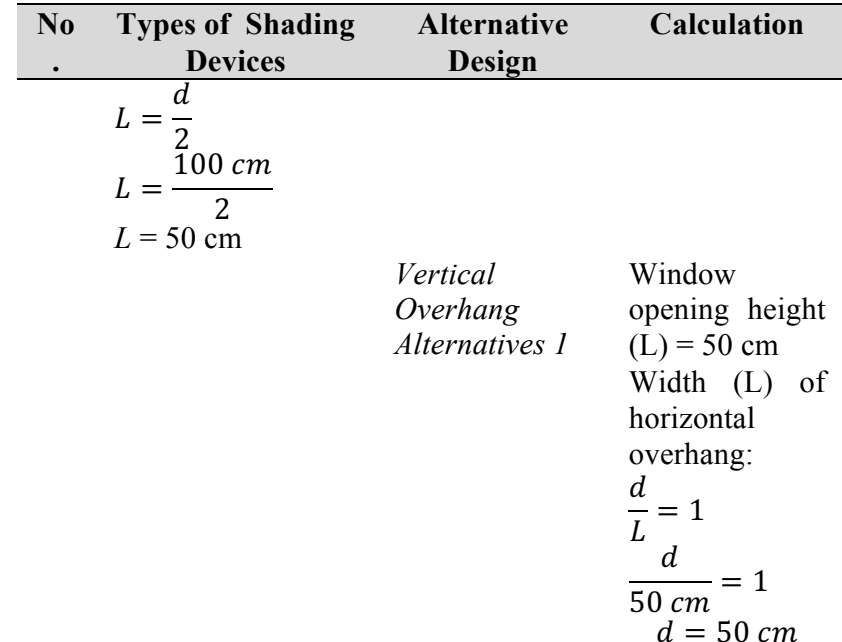

the distance between the louvers on the vertical fin used is $50 \mathrm{~cm}$.
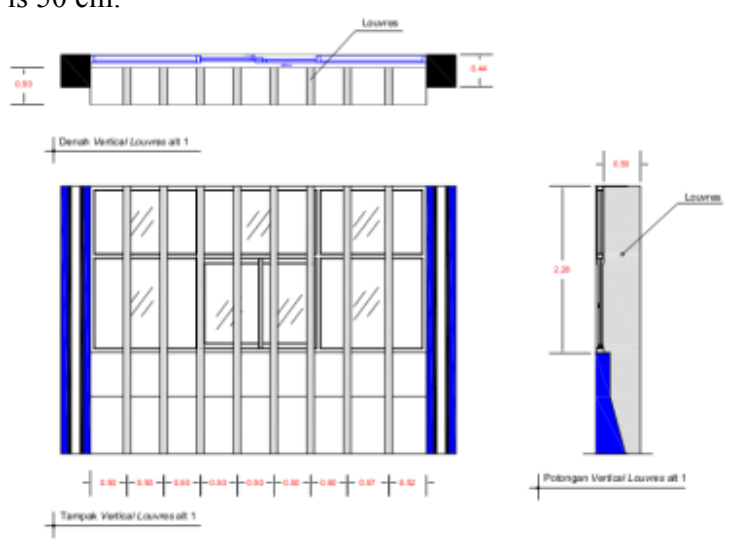

6

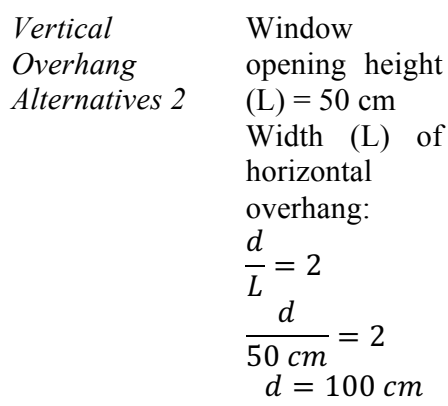

the distance between the louvers on the vertical fin used is $100 \mathrm{~cm}$.
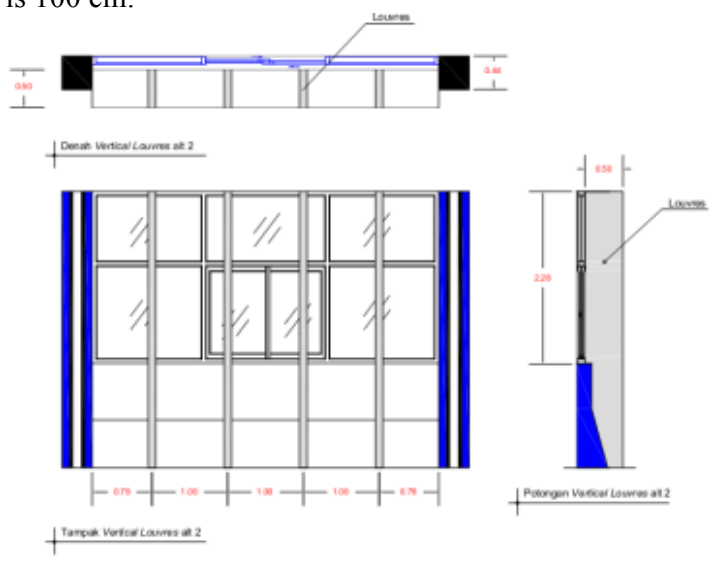


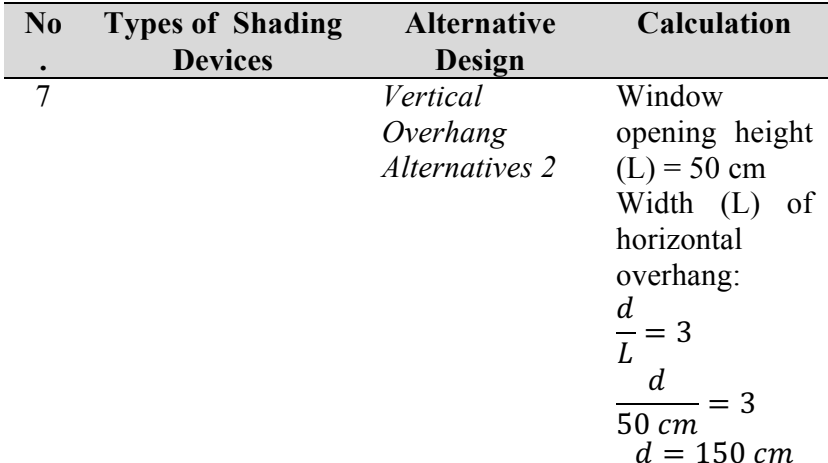

the distance between the louvers on the vertical fin used is $150 \mathrm{~cm}$.

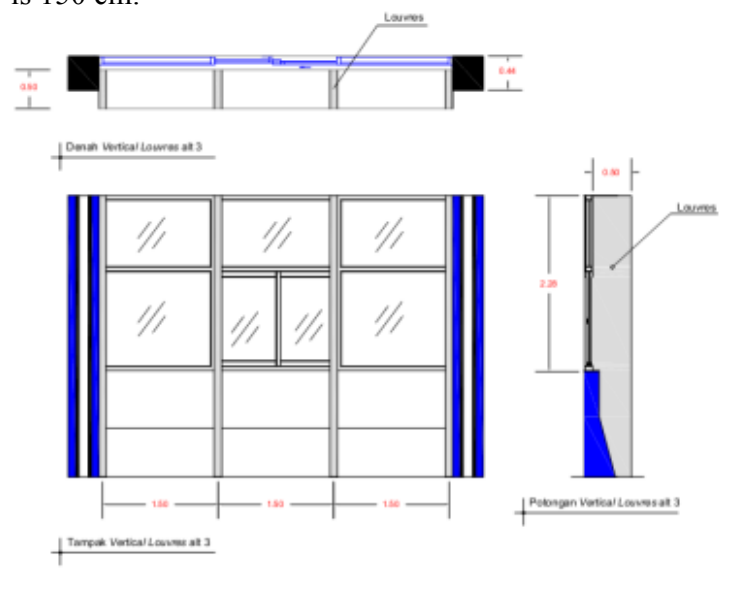

\section{RESUltS AND DisCUSSION}

\section{A. Simulation of Existing Condition of Library Reading Room}

Simulation of existing library reading room conditions is carried out to determine the value of natural lighting intensity using DiaLux Evo 8.1 software. The results of the simulation with this software will be compared with the results of manual measurement. Existing condition simulations were carried out in June 2019 at $09.00 \mathrm{WIB}, 11.00 \mathrm{WIB}$, and 15.00 WIB. The results of the existing condition simulation will be shown as follows:

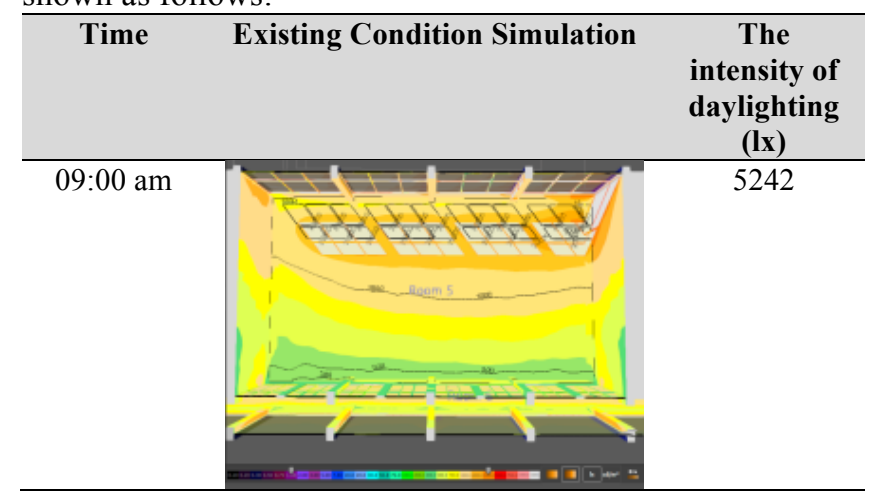

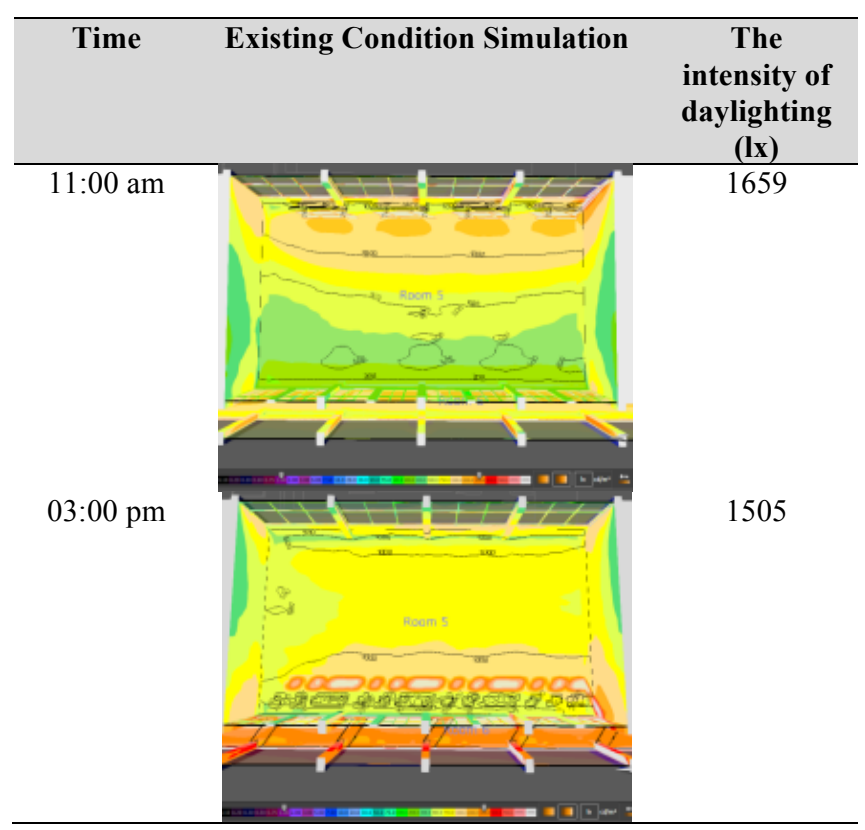

The simulation results of the existing library reading room conditions on Monday, June 10, 2019, can be seen in table 3:

TABLE 3. SIMULATION RESULTS OF EXISTING LIBRARY READING ROOM

CONDITIONS

\begin{tabular}{|c|c|c|c|}
\hline $\begin{array}{c}\text { Simulation } \\
\text { Time }\end{array}$ & $\begin{array}{c}\text { The intensity } \\
\text { of natural } \\
\text { lighting (lx) }\end{array}$ & $\begin{array}{c}\text { Average } \\
\text { Natural } \\
\text { Lighting } \\
\text { Intensity (lx) }\end{array}$ & $\begin{array}{c}\text { Daylight } \\
\text { Factor } \\
\text { (\%) }\end{array}$ \\
\hline $09.00 \mathrm{am}$ & 5242 & \multirow{2}{*}{2802} & \multirow{2}{*}{4,263} \\
\hline $11.00 \mathrm{am}$ & 1659 & & \\
\hline $15.00 \mathrm{pm}$ & 1505 & & \\
\hline
\end{tabular}

Based on the simulation results, the natural lighting intensity of the library reading room is $2802 \mathrm{~lx}$. This lighting intensity exceeds the standard lighting intensity for the library reading room which is $300 \mathrm{~lx}$. The daytime factor in the existing condition is $4.263 \%$, the daylight factor for the library should be $5 \%$ so the daylight factor does not meet the standards.

This causes the reading room to be over-lighting intensity, resulting in glare. The solution to this problem can be in the form of a design of shading devices to reduce excess lighting intensity and reduce glare, so that reader comfort can be achieved. 
B. Simulation of Horizontal Overhang Shading Devices Simulation

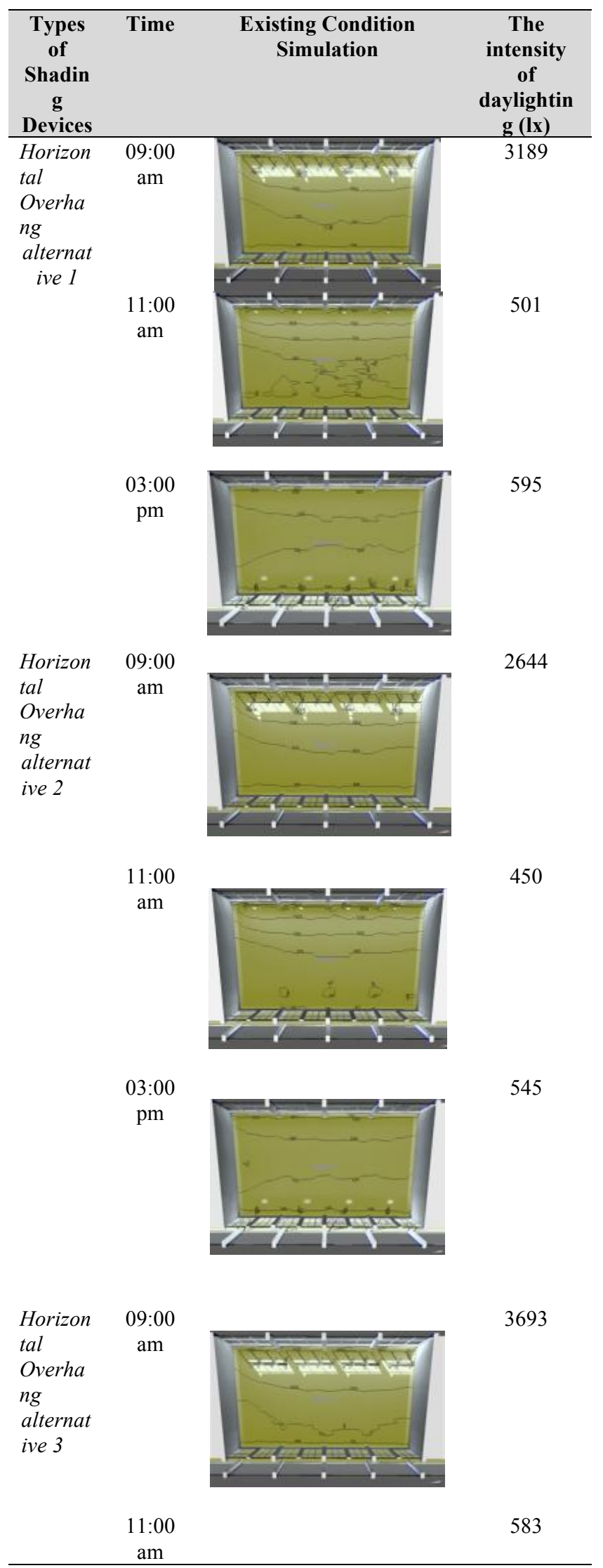
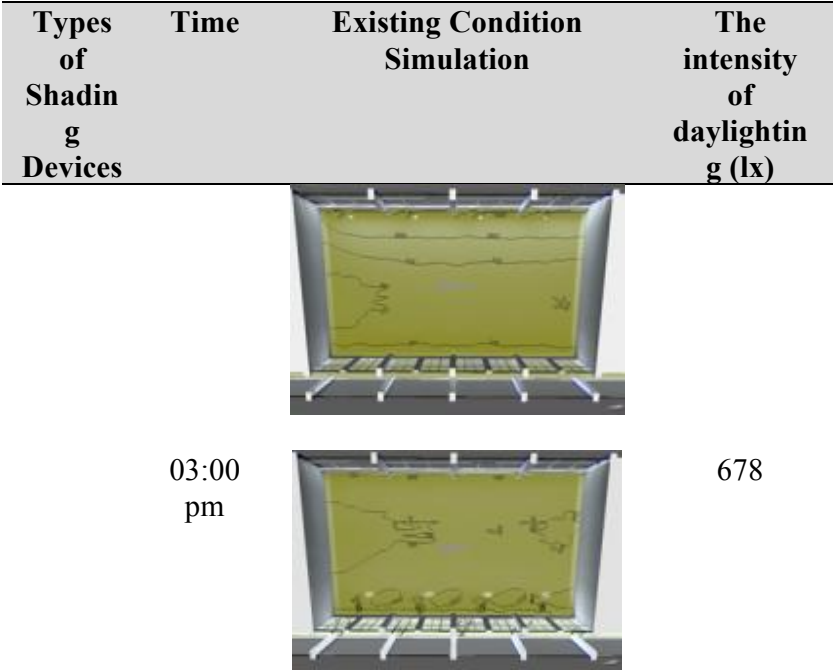

678

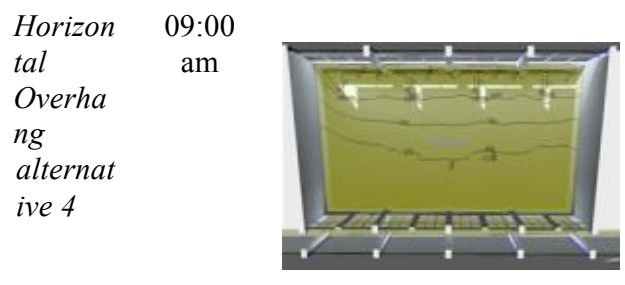

1113
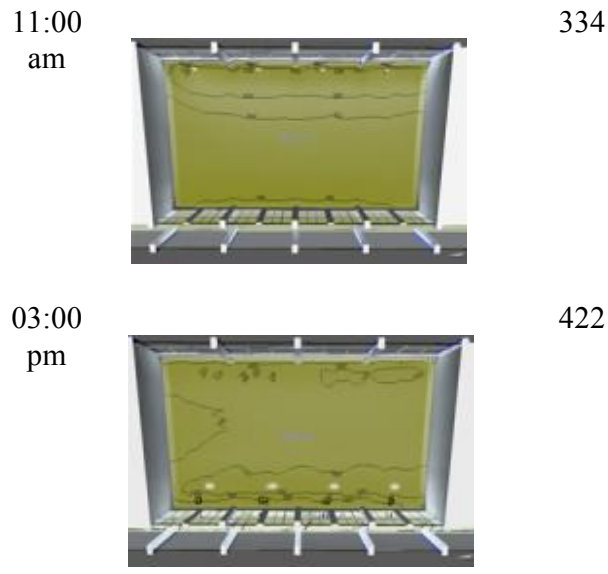

C. Simulation of Vertical Overhang Shading Devices Simulation

\begin{tabular}{cccc}
\hline $\begin{array}{c}\text { Types of } \\
\text { Shading } \\
\text { Devices }\end{array}$ & Time & $\begin{array}{c}\text { Existing Condition } \\
\text { Simulation }\end{array}$ & $\begin{array}{c}\text { The } \\
\text { intensity of } \\
\text { daylighting } \\
\text { (lx) }\end{array}$ \\
\hline $\begin{array}{c}\text { Vertical } \\
\begin{array}{c}\text { Overhang } \\
\text { alternativ } \\
\text { e 1 }\end{array}\end{array}$ & $\begin{array}{c}09: 00 \\
\text { am }\end{array}$ & 558 \\
\\
\end{tabular}




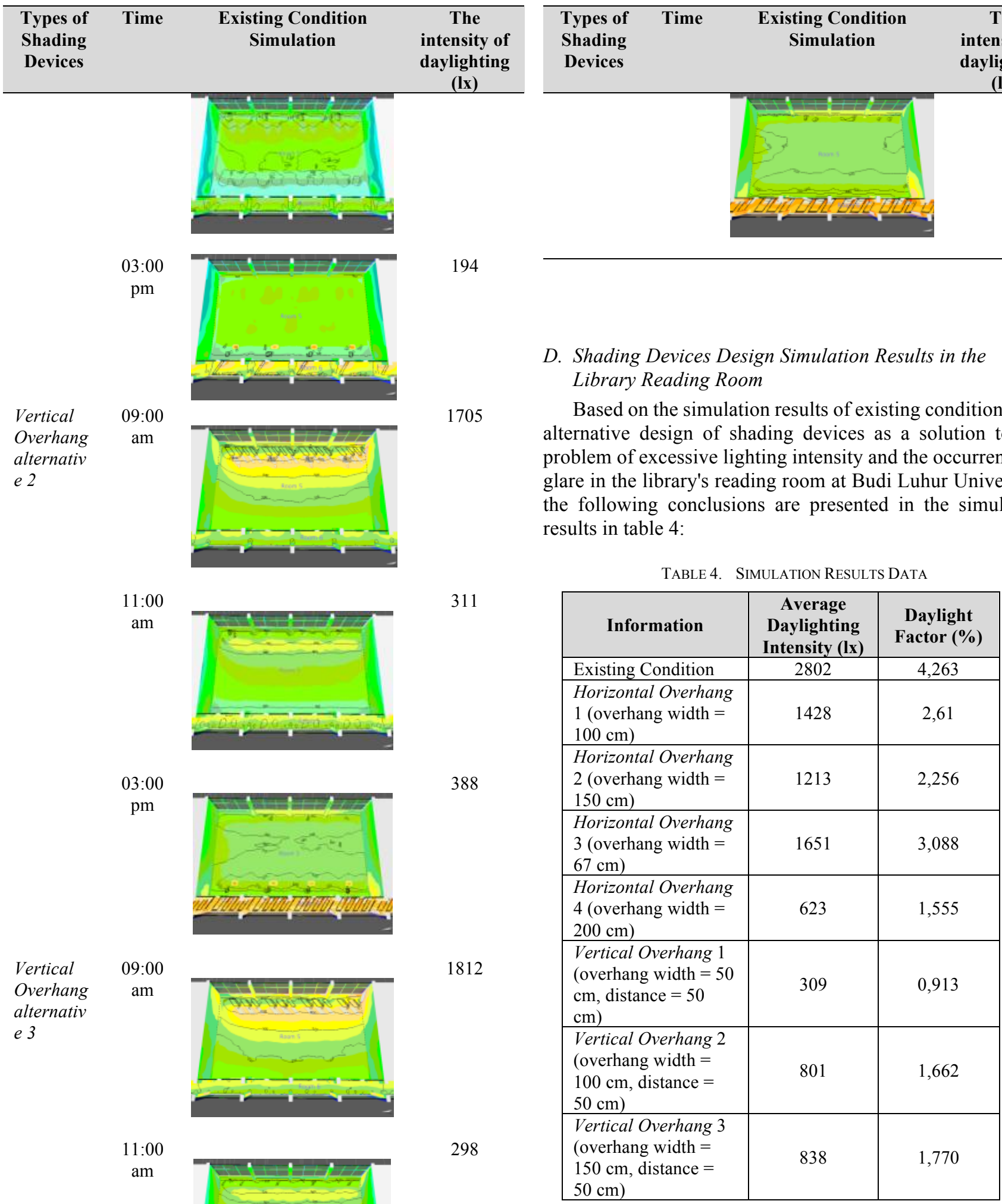

Based on the results of simulations that have been carried out on several alternative design shading devices, it can be seen that by using shading devices excessive lighting intensity in library reading rooms can be reduced so that glare problems can be resolved. From various shading devices design alternatives, it can be seen that the vertical overhang 1 design with overhang width $=50 \mathrm{~cm}$ and vertical fin distance $=50 \mathrm{~cm}$ ) which maximally reduces the natural lighting intensity, from the lighting intensity of the existing conditions 
alternative horizontal overhang 4 design with overhang width of $200 \mathrm{~cm}$.

$28021 x$ to $3091 x$ and almost meets the standard lighting intensity for the library reading room is $300 \mathrm{~lx}$.

Similar research was conducted by Primastiti Wening Mumpuni, Rahmanu Widayat and Silfia Mona Aryani in 2017 concerning Natural Lighting in the Reading Room of the Surabaya Public Library. This research concludes is that the daylight in the reading room of Surabaya's public library does not meet the recommended standards. These conditions can be improved by adding openings of the right size and arrangement of furniture that does not block the lighting. This research did not provide a design solution that only added furniture openings and arrangements. While this research resulted in a design solution in the form of shading devices that can answer research questions. This is what distinguishes the research conducted by Primastiti and friends with this research.

\section{CONCLUSIONS}

Based on data processing, analysis, and synthesis of the problem of excessive lighting intensity so that the glare in the library reading room at the 3rd floor of Budi Luhur University, the conclusions can be drawn as follows:

1. The simulation results of the existing condition of the library reading room obtained the average value of the natural lighting intensity in the reading room on the $3 \mathrm{rd}$ floor of the library of Budi Luhur University is 2802 1x.

2. Shading devices can reduce excessive lighting intensity so that glare problems can be resolved.

3. The optimal design of horizontal overhang shading devices that can reduce lighting intensity is
4. The most optimal design of vertical overhang shading devices that can reduce lighting intensity is alternative vertical overhang design 1 with overhang width of $50 \mathrm{~cm}$ and vertical fin distance of every 50 $\mathrm{cm}$.

\section{REFERENCES}

[1] Soegijanto, Bangunan di Indonesia dengan Iklim Tropis Lembab Ditinjau dari Aspek Fisika Bangunan. Jakarta, Indonesia: Direktorat Jenderal Pendidikan Tinggi, Departemen Pendidikan dan Kebudayaan, 1998.

[2] Norbert Lechner, Heating, Cooling, Lighting Metode Desain untuk Arsitektur, Kedua. Jakarta, Indonesia: Rajagrafindo Persada, 2001.

[3] P. Manurung, Desain Pencahayaan Arsitektural. Yogyakarta: ANDI, 2009.

[4] N. Jamala, N. Soewarno, J. A. Suryabrata, and A. Kusumawanto, "Kenyamanan Visual Ruang Kerja Kantor," vol. 35, pp. 12-20, 2013.

[5] Norbert Lechner, Heating, Cooling, Lighting, Kedua. PT. Rajagrafindo Persada, 2007.

[6] S. N. Indonesia and B. S. Nasional, "Konservasi energi pada sistem pencahayaan," 2011.

[7] A. Hidayat, "Pengertian dan Penjelasan Penelitian Kuantitatif Lengkap," $2012 . \quad$ [Online]. Available: https://www.statistikian.com/2012/10/penelitian-kuantitatif.html. [Accessed: 31-Mar-2019].

[8] Sutrisno Hadi, Metodologi Research Jilid 4. Yogyakarta, Indonesia: Yayasan Penerbit Fakultas Psikologi UGM, 1985. 